\title{
Root Development of Permanent Incisors and Mandibular Molars in Correlation with Treatment Plan
}

\author{
Yordan Tarpomanov' , Sevda Rimalovska ${ }^{1}$, Ani Belcheva ${ }^{1}$, Miroslava Yordanova², \\ Svetla Yordanova ${ }^{2}$, Maria Kukleva ${ }^{1}$ \\ ${ }^{1}$ Department of Pediatric Dentistry, Faculty of Dental Medicine, Medical University of Plovdiv, Plovdiv, Bulgaria \\ ${ }^{2}$ Department of Orthodontics, Faculty of Dental Medicine, Medical University of Plovdiv, Plovdiv, Bulgaria
}

\section{Correspondence: \\ Yordan Tarpomanov, Department of Pediatric Dentistry, Faculty of Dental Medicine, Medical Uni- versity of Plovdiv, 2 Hristo Botev Blvd., 4000 Plovdiv, Bulgaria E-mail: iortarp@yahoo.com Tel: 00359898455561}

Received: 02 July 2017

Accepted: 11 Sept 2017

Published Online: 02 Oct 2017

Published: 30 June 2018

Key words: root development, Demirjian's method, treatment plan

Citation: Tarpomanov $Y$, Rimalovska S, Belcheva A, Yordanova $M$, Yordanova S, Kukleva M. Root development of permanent incisors and mandibular molars in correlation with treatment plan. Folia Med (Plovdiv) 2018;60(2): 283-90.

doi: 10.1515/folmed-2017-0093
Background: The incisors and molars play a major role in the formation and function of permanent dentition. Much research has been devoted to investigating the eruption of teeth and their root development.

Aim: To study the root development of permanent incisors and mandibular molars in correlation with treatment plan and proper treatment protocols.

Materials and methods: The Demirjian's method was used to assess the root development of incisors and mandibular molars in children between 7 and 12 years old.

Results: In 7-year-old children most of the lower first mandibular molars (76\%) had complete root length, but open apices. Eighty-two percent of the roots of the first mandibular molars of the 8-year-old children and 54\% of these molars of the 9 -year-old children were with open apices. The first mandibular molars had incomplete roots in the 10-year-olds (6\%) and even in the 11-year-old children (4\%). We detected Stage E in $32 \%$ of the 10 -year-olds and in $24 \%$ of the 11 -year-old children. Even in 12-year-old children we found Stage E in $4 \%$ of them from their panoramic X-rays. We detected complete root development in all of the children at the age of 12 .

Conclusions: Dental practitioners have to wait until the age of 10,11 and even 12 to extract the first molars, when the furcation is formed. Proper clinical examination and diagnostic radiographs should be done before the beginning of the treatment of molars and incisors at the age between 7 and 12 .

\section{BACKGROUND}

The incisors and molars have a major role to play in the in formation and function of permanent dentition. There is a large body of evidence pointing to the fact that there is high risk of dental trauma in the incisors ${ }^{1-5}$ and also high caries risk of the first permanent molars at the age between 7 and 12 years ${ }^{6,7}$. Also some types of dysplasia can increase the risk of severe caries at that age, especially molar-incisor hypomineralization because of the high frequency of this dysplasia. 8,9

Dental trauma and caries can lead to pulp involvement and loss of tooth's vitality with possible infection before the end of the root development. Lack of attention towards the stage of root development can lead to usage of routine endodontic protocols and as a result severe complications and finally extraction of permanent teeth in children and adolescents. On the other hand, sometimes extraction is needed when the first permanent molars are severely compromised. In such cases the stage of the root development of second permanent molar is crucial for parallel movement of this tooth. ${ }^{10}$ There are a lot of studies investigating the eruption of the teeth and their root development. ${ }^{11,12}$ Nevertheless, investigations of root development of permanent incisors and mandibular molars in correlation with treatment plan could be very useful for dental practice. One of the well known methods used to assess root development is the Demirjian's method. ${ }^{13}$ There have been studies to use the Demirjian's method to access the connection between dental and chronological age $\mathrm{e}^{14-17}$ and also root development as an indicator for chronological 
age, used by forensic dentistry ${ }^{18,19}$.

\section{AIM}

To find a correlation between stages of root development in children aged 7 to 12 years and the proper clinical protocols that can be used.

\section{MATERIALS AND METHODS}

In the present study, we analysed 300 panoramic radiographs of children aged between 7 and 12 years (170 girls and 130 boys) from the town of Plovdiv, Bulgaria. They were divided into 6 groups of 50 radiographs in each age group. The study was conducted in the Department of Pediatric Dentistry and Orthodontics in the Faculty of Dental Medicine, Plovdiv, Bulgaria. The units of our research were 3600 teeth (permanent incisors and mandibular molars). The maxillary molars were not included in our study because of difficulties in determining the stages of their root development on the panoramic X-rays. The points of observation were: age, gender of children and stages of development of crowns and roots of investigated teeth, assessed by Demirjian's method. ${ }^{13}$

There were 50 children in each age group divided into two subgroups by gender. Assessment of the tooth's development stages was made by the panoramic radiographs using Demirjian's method with plastic ruler. As categorised by Demirjian, the stages of dental formations are as follows:

Stage A: In both uniradicular and multiradicular teeth, a beginning of calcification is seen at the superior level of the crypt in the form of an inverted cone or cones. No fusion of these calcification points is observed.

Stage B: Fusion of calcified points forms one or several cusps which unite to give a regularly outlined occlusal surface.

Stage C: Enamel formation is complete at the occlusal surface, dentine deposition has started and the pulp chamber has a curved shape at the occlusal border.

Stage D: Crown formation is complete, extending down to the cemento-enamel junction. Beginning of root formation is seen in the form of a spicule.

Stage E: The walls of the pulp chamber form straight lines. The root length is less than the crown height. In molars the formation of the radicular bifurcation is seen like a calcified point or a semi-lunar shape.

Stage F: The walls of the pulp chamber form an isosceles triangle. The apex ends in a funnel shape. The root length is equal to or greater than the crown height.

Stage G: The walls of the root canal are parallel and the apical end is still partially open.

Stage H: The apical end of the root is completely closed and the periodontal membrane has a uniform width around the tooth apex.

The results were presented in tables and the data were analysed using Microsoft Excel and SPSS ver. 19.0.

\section{RESULTS}

Table 1 shows the distribution of studied children

Table 1. Distribution of studied children by age and gender

\begin{tabular}{lccccccc}
\hline \multicolumn{1}{c}{ Age } & $\mathbf{7}$ & $\mathbf{8}$ & $\mathbf{9}$ & $\mathbf{1 0}$ & $\mathbf{1 1}$ & $\mathbf{1 2}$ & Total \\
\hline Gender & & & & & & & \\
Boys & 20 & 20 & 29 & 20 & 20 & 21 & 130 \\
Girls & 30 & 30 & 21 & 30 & 30 & 29 & 170 \\
Total & 50 & 50 & 50 & 50 & 50 & 50 & 300 \\
\hline
\end{tabular}

by age and gender.

We found no statistically significant difference in the root development between boys and girls in each age group and also between the same teeth on the left and the right side of the same jaw ( $>0.05)$ in contrast with well known data in scientific literature. ${ }^{11}$

We found that in 7 years old children, the length of the root is equal to or bigger than the length of the crown in 58\% of upper central incisors (Stage F) and we established complete root development in $8 \%$ of the cases (Stage H). In 8-year-olds we found complete root development in almost half of the upper central incisors (46\%), and in $42 \%$ the apical constriction of the roots was still not formed (Stage G). Only 12\% of the upper incisors' roots didn't reach their final length at the age of 8 (Fig. 1).

In the upper lateral incisors we didn't find complete root development in 7-year-old children. In this age group most of the teeth were in Stage F. In the 8 -year-olds, only $18 \%$ of the upper lateral incisors' roots had closed apices. We found complete root development in almost half of the upper lateral incisors (46\%) in 9-year-olds, and in $76 \%$ in 10-year-old children. Even at 11 years of age we established incomplete root development in $2 \%$ of the investigated upper central and in $6 \%$ of the upper lateral incisors. The present study showed that the root development of upper incisors was fully completed at the age of 12 years (Fig. 2). 


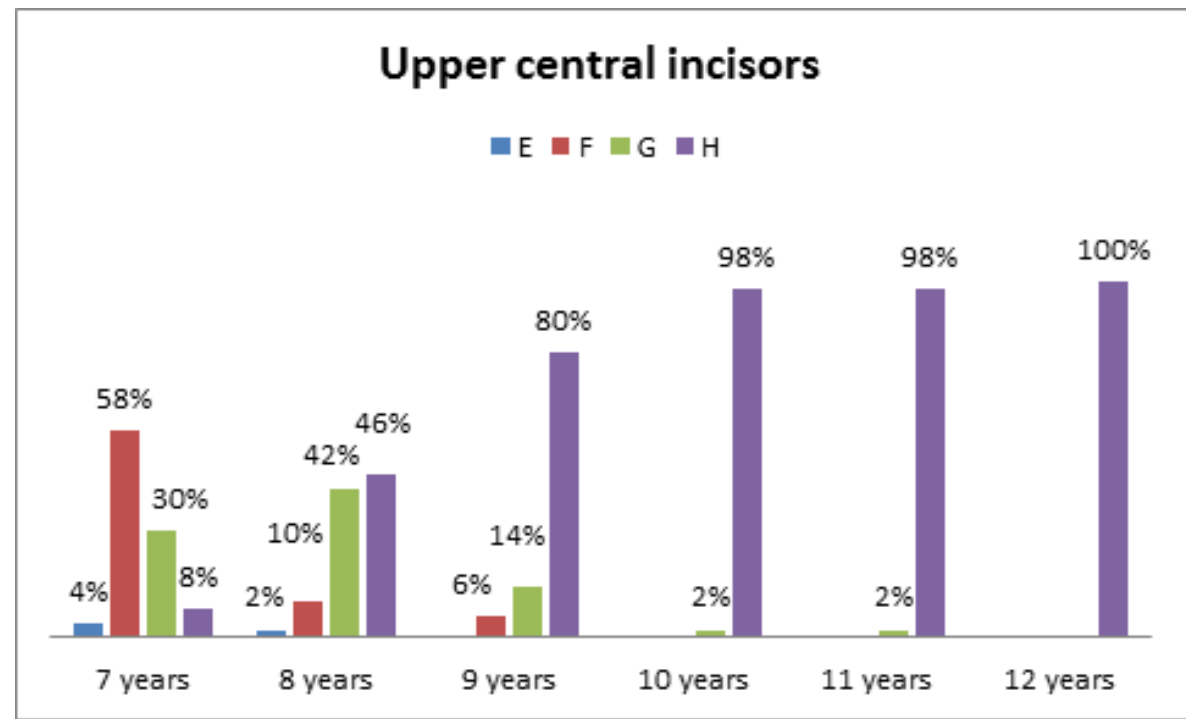

Figure 1. Root development of the upper central incisors.

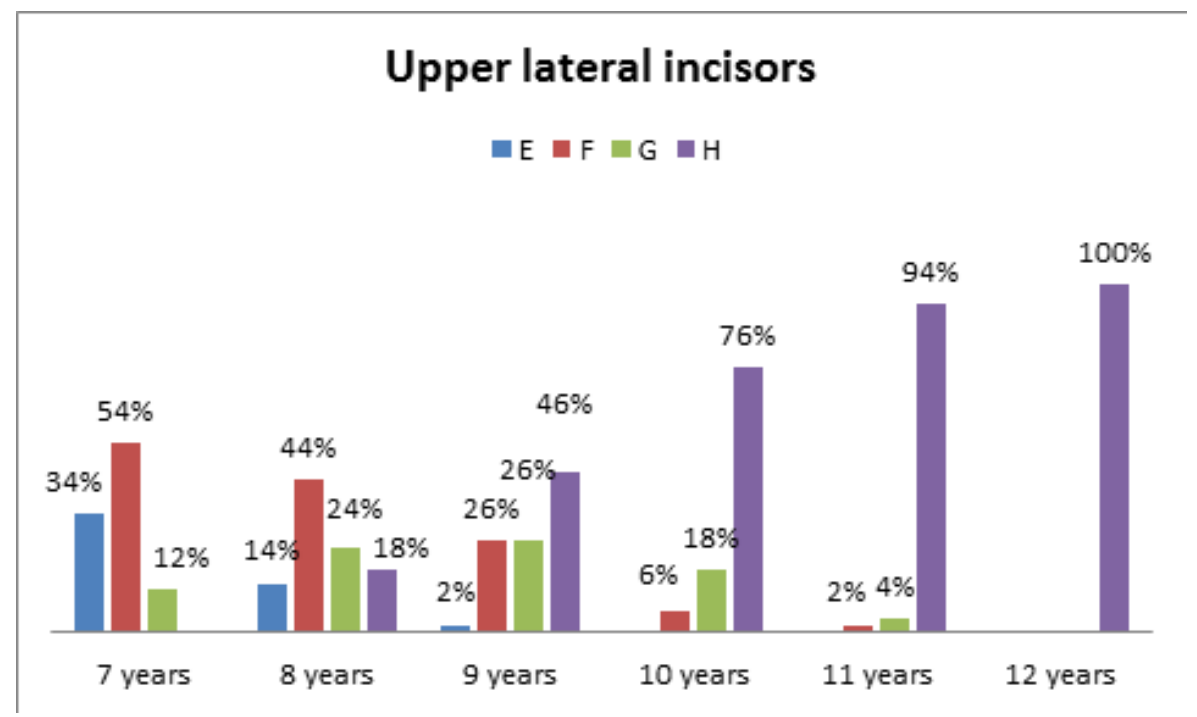

Figure 2. Root development of upper lateral incisors.

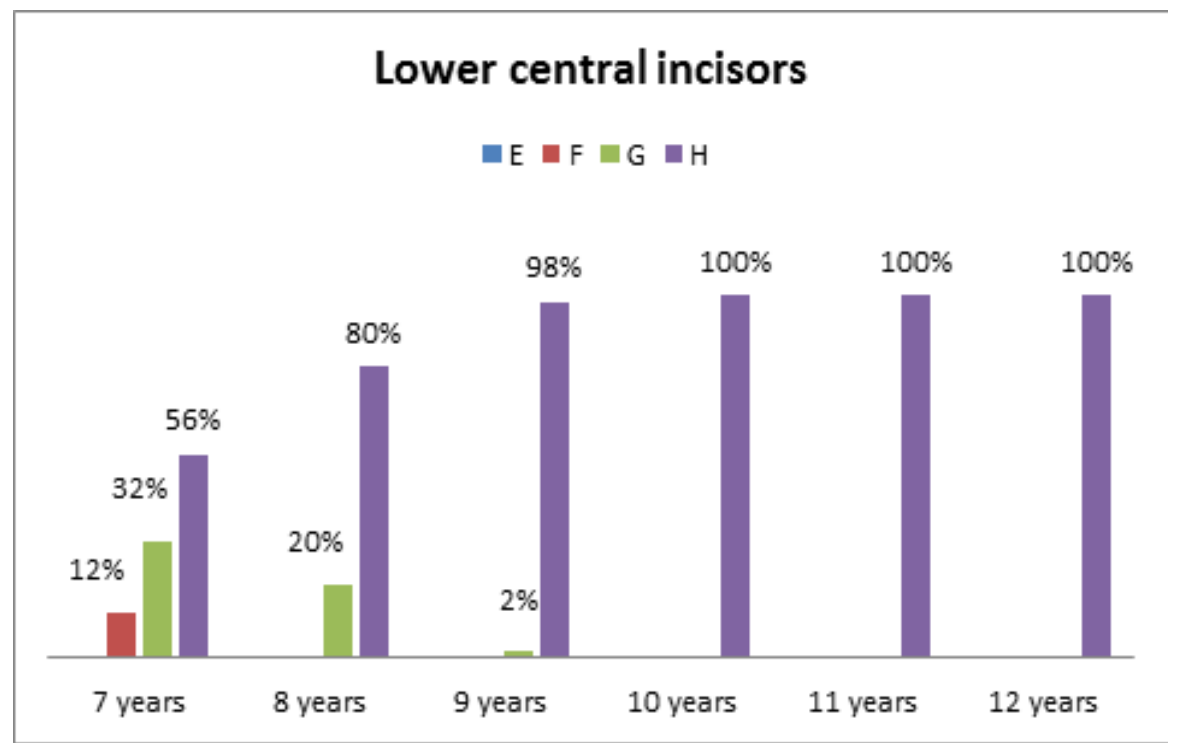

Figure 3. Root development of lower central incisors. 


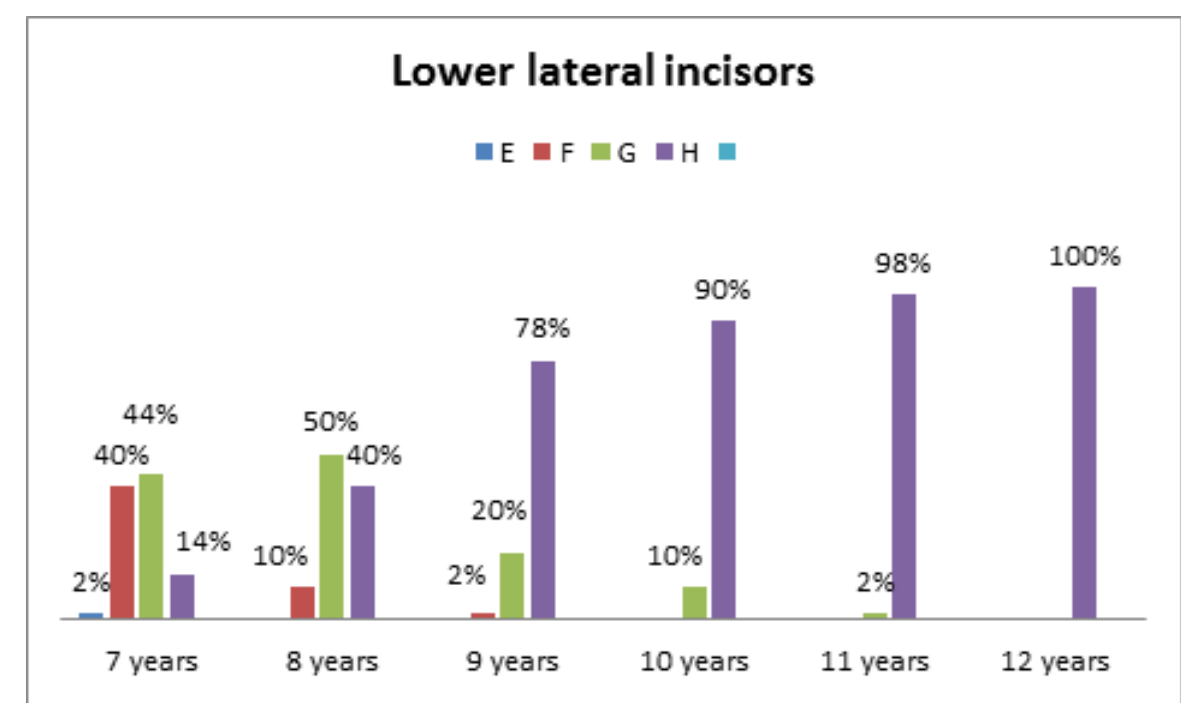

Figure 4. Root development of lower lateral incisors.

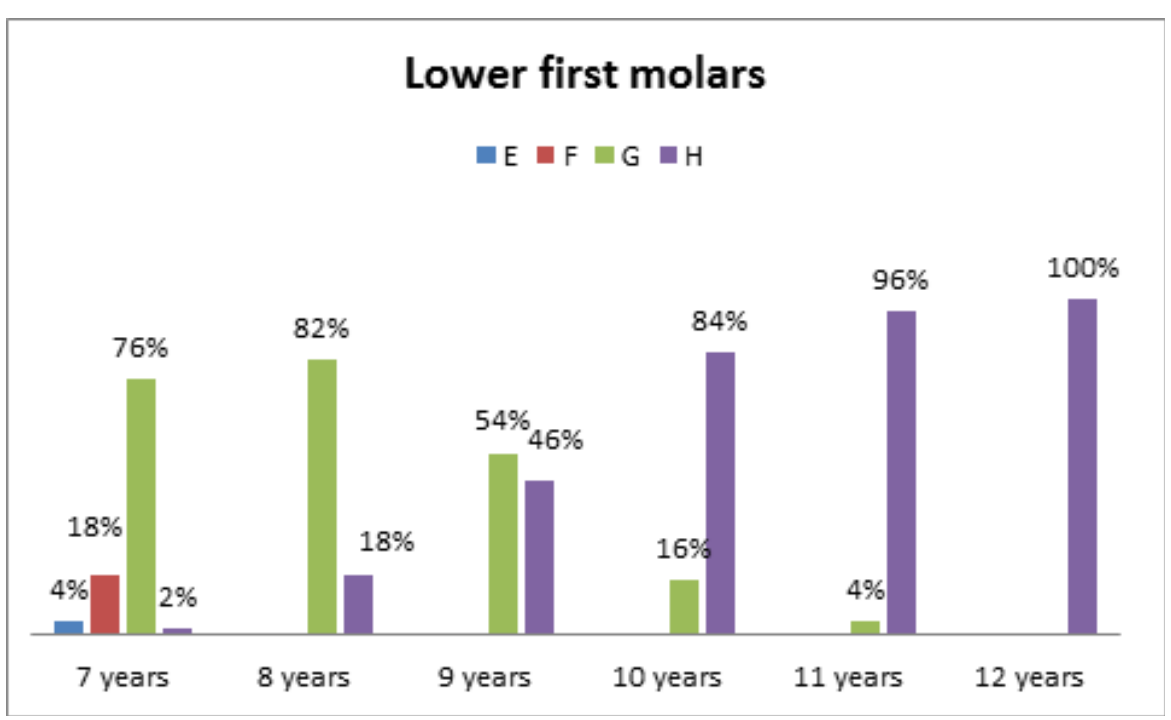

Figure 5. Root development of lower first molars.

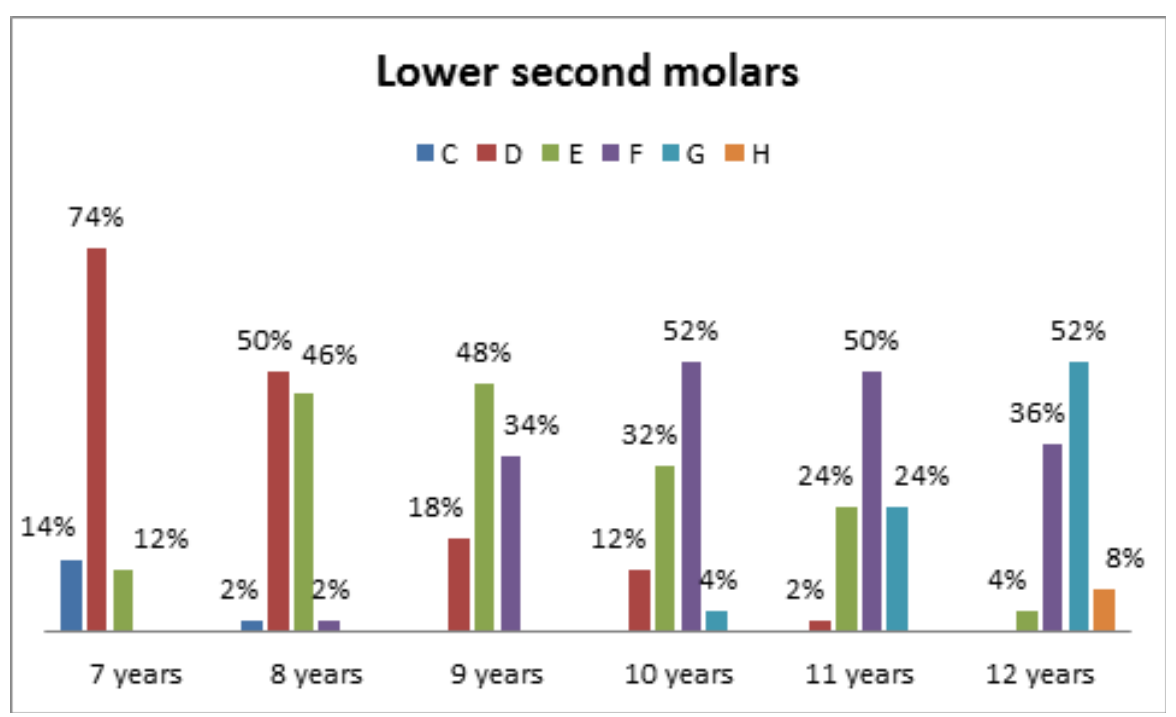

Figure 6. Root development of lower second molars. 
We found complete root development in significant percentage $(62 \%)$ of the lower central incisors in 7-year-old children. This percentage is higher at the age of 8 years (78\%). Only in $2 \%$ of the investigated lower central incisors in 9and 10-year-old children showed incomplete root development (Fig. 3).

We established that $12 \%$ of the lower lateral incisors in 7-year-old children showed complete root development. Our results suggest that $22 \%$ of the 9 -year-olds and $16 \%$ of the 10 -year-old children had lower lateral incisors with incomplete root development. We found that $100 \%$ of the children completed root development in the lower central incisors at the age of 11 and $100 \%$ of them completed the root development in the lower lateral incisors at the age of 12 (Fig. 4).

We found that in the 7-year-old children most of the lower first mandibular molars $(76 \%)$ had complete root length, but with open apices ( Stage G). Lower percentage from the investigated first permanent molars didn't reach their full root length (Stage F) and in $4 \%$ of the children, the length of already formed roots was shorter than their crowns (Stage E). Eighty-two percent of the roots of the first mandibular molars at the age of 8 years and $54 \%$ of the 9 -year-old children were with open apices. The result of the present study suggest that the first mandibular molars had incomplete root development in 10-year-old children (6\%) and even in 11-year-old (4\%) children. We detected complete root development in all of the children at the age of 12 (Fig. 5).

According to our investigation $12 \%$ of the investigated lower second mandibular molars at 7 years old children, the root development had already started (Stage E). According to the literature this stage of the second molar is an appropriate period for extraction of severely compromised first permanent molars. We detected Stage E of the second permanent molars in $46 \%$ of 8 -year-olds and in $48 \%$ of 9 -year-old children. In the 10 -year-old children we found Stage E in $32 \%$ of them and in $24 \%$ of 11 -year-old children. Even in 12-year-old children we found Stage $\mathrm{E}$ in $4 \%$ of them from our panoramic X-rays (Fig. 6).

\section{DISCUSSION}

The root development of permanent incisors and molars play a major role in the development of the dentition and can have an important role to play in the treatment planning for both orthodontists and pediatric dentists. Trauma to the anterior teeth, commonly found among young children accounts for one third of all traumatic injuries in boys and one fourth of all injuries in girls. ${ }^{20}$ Tooth fracture constitutes $4 \%-5 \%$ and luxation injuries $30 \%-44 \%$ of all dental trauma injuries. ${ }^{21,22}$ Because of their position, the anterior teeth tend to bear the brunt of many impact injuries. The injuries vary from avulsion to intrusion, lateral displacement, fracture, or just a concussion. In many cases, the injury causes cessation of tooth development. Because the root development takes place after the tooth has erupted into the oral cavity, an incompletely formed apex is one of the most common features seen in traumatized teeth.

The interpretation of our investigation showed that the most critical period for root canal treatment of permanent incisors is until the age of 9, because of the highest percentage of incomplete root development before that age. Our study also showed possibility of incomplete root development in the central incisors at the age of 11 and in the lateral incisors at the age of 12 . These results emphasize the necessity of pre-operative X-ray and special clinical approach treating incisors at that age. In such cases our recommendations for dental practitioners are to use treatment protocols that can preserve pulp's vitality and can ensure root development like pulp capping, partial or total pulpotomy. ${ }^{23-25}$ If preserving the vitality is not possible, proper protocols for non-vital teeth with incomplete root development have to be used - apexification or revascularization. ${ }^{26-28}$ The more root development is incomplete, the higher is the success rate of revascularization. ${ }^{29}$

It is well known that the first permanent molars have main role in the occlusion. Edward Angle, who is considered the father of modern orthodontics, based his classification of malocclusions on the relative position of the permanent first molar. ${ }^{30}$ Angle believed that the anteroposterior dental base relationship could be assessed reliably from first permanent molar relationship, as its position remained constant following eruption.

Many years later, Andrews ${ }^{31}$ pointed the first permanent molars as one of the most important keys for normal occlusion. As we mentioned before, there is higher caries risk and also risk of pulp involvement before or during the treatment of the first molars at the age between 7 and 12 .

Our investigation of the first permanent molars reveals the necessity of the special attention to 
the root development of these teeth until the age of 12 , because it can be incomplete even at the age of 11. Our recommendations in such cases include pre-operative $\mathrm{X}$-rays and proper treatment protocols have to be used to decrease the risk of pulp exposure and to ensure the continuing of the root development of the first molars.

The situation is different for the second molars. There is no risk of severe caries and pulp involvement until the age of 12 , because these teeth are erupted soon before or even after that age. Yet, the investigation of the root development of the second molars in the period between 7 and 12 years is important, especially if there is severely compromised first molars. The first permanent molar is rarely the tooth of choice for extraction prior to orthodontic treatment. However, there are various clinical situations in which extraction of first permanent molars should be considered: extensively carious first permanent molars; hypoplastic or hypomineralized first permanent molars, heavily restored first permanent molars where premolars are perfectly healthy; apical pathoses or endodontically treated first permanent molars; crowding at the distal aspect of the arches and third molars of reasonable form and in reasonable position; skeletally divergent malocclusions (dolichofacial vertical pattern); and anterior open bite malocclusion. There are several factors that require careful consideration when a compromised first permanent molar is detected and it was mentioned the importance of timely extraction of the first permanent molar for better orthodontic perspective - parallel movement of the second molar on its place. When a lower first permanent molar is extracted at the ideal stage, a maximum amount of spontaneous mesial movement of the unerupted second permanent molar can be expected. This in turn can significantly improve the possibility for successful eruption of the lower third molar. Even if a small space does eventually remain between the second permanent molar and second premolar tooth, this can be easily closed with fixed appliance therapy. The data from the scientific literature describe that the best period to extract severely compromised first permanent molars is between 8 and 9 years of age, when it is expected that the furcation between the roots is formed and the root development has already begun. ${ }^{32-35}$ Our study reveals that sometimes dental practitioners have to wait until the age of 10,11 and even 12 to extract the first molars at the most appropriate time, when the furcation is already formed (Stage E). Extraction of compromised first permanent molars and subsequent comprehensive orthodontic treatment may not always be the preferred treatment option. However, if the prognosis of any first permanent molars is poor and a significant malocclusion exists, removal of any compromised teeth in conjunction with orthodontic treatment can provide rewarding outcomes. ${ }^{32}$

\section{CONCLUSIONS}

The data from our research confirm the necessity of investigation of the root development before treatment of dental trauma and deep carious lesions of incisors and molars at the age between 7 and 12 . At this period we determined possible risk of pulp involvement before the end of the root development. Our recommendations for dental practitioners are to make proper clinical examination and diagnostic radiographs before the beginning of the treatment of molars and incisors at the age between 7 and 12 and also to use specific treatment protocols, depend on the clinical cases. This would decrease possibility of treatment mistakes, which lead to unacceptable damages or even extractions of permanent teeth.

\section{REFERENCES}

1. Glendor U, Marcenes W, Andreasen JO. Epidemiology of traumatic dental injuries - a 12-year review of the literature. Dent Traumatol 2008;24(6):603-11.

2. Diangelis AJ, Andreasen JO, Ebeleseder KA, et al. International Association of Dental Traumatology guidelines for the management of traumatic dental injuries: 1. Fractures and luxations of permanent teeth. Dent Traumatol 2012;28:2.

3. Andersson L, Andreasen JO, Day P, et al. International Association of Dental Traumatology guidelines for the management of traumatic dental injuries: Avulsion of permanent teeth. Dent Traumatol 2012;28:88.

4. Zaragoza AA, Catalá M, Colmena ML, et al. Dental trauma in school children six to twelve years of age. ASDC J Dent Child 1998;65(6):492-4, 439.

5. Glendor U, Marcenes W, Andreasen JO. Classification, epidemiology and etiology. In: Andreasen JO, Andreasen FM, Andersson L, editors. Textbook and color atlas of traumatic injuries to the teeth, 4th ed. Chapter 8. Oxford: Blackwell Munksgaard; 2007:226.

6. Ali NS, Ali NS, Khan M, et al. Prevalence of dental caries in the first permanent molars in children between 8-12 years. J Pak Dent Assoc 2013;22(2): 119-23.

7. Khalid HM Al-Samadani, Mohammad SA. Prevalence of first permanent molar caries in and its 
relationship to the dental knowledge of 9-12-year olds from Jeddah, kingdom of Saudi Arabia. ISRN Dent 2012;2012:391068.

8. Kukleva M, Petrova S, Kondeva V, et al. Molar incisor hypomineralisation in 7-to-14-year-old children in Plovdiv, Bulgaria - an epidemiologic study. Folia Med (Plovdiv) 2008;50(3):71-5.

9. Meligy OAESE, Alaki SM, Allazzam SM. Molar incisor hypomineralization in children: a review of literature. Oral Hyg Health 2014;2(4):139.

10. Williams JK, Gowans AJ. Hypomineralised first permanent molars and the orthodontist. Eur J Paediatr Dent 2003;4:129-32.

11. Nanci A. Ten Cate's Oral Histology. 8th ed. Elsevier Health Sciences; 2013:251.

12.Logan W, Kronfeld R. Development of the human jaws and the surrounding structures from birth to the age of 15 years. J Am Dent Assoc 1933;20:379-427.

13. Demirjian A, Goldstein H, Tanner M. A new system of dental age assessment. Hum Biol 1973;45:211-27.

14. Baghdadi ZD, Pani SC. Accuracy of populationspecific Demirjian curves in the estimation of dental age of Saudi children. Int J Paediatr Dent 2012;22(2):125-31.

15. Jurca A, Lazar L, Pacurar M, et al. Dental age assessment using Demirjian's method - a radiographic study. ESJ 2014;10(36):51-60.

16. Hedge RJ, Sood PB. Dental maturity as an indicator of chronological age: radiographic evaluation of dental age in 6 to 13 years children of Belgaum using Demirjian methods. J Indian Soc Pedod Prev Dent 2002;20(4):132-8.

17. Leurs IH, Wattel E, Artman IH, et al. Dental age in Dutch children. Eur J Orthod 2005;27(3):309-14.

18. Manjunatha B, Soni N. Estimation of age from development and eruption of teeth. J Forensic Dent Sci 2014;6(2):73-6.

19. Amitha L, Karen B, Nagesh R, et al. Demirjian's method in the estimation of age: a study on human third molars. J Forensic Dent Sci 2015;7(2):153-7.

20. Gassner R, Bösch R, Tuli T, et al. Prevalence of dental trauma in 6000 patients with the facial injuries. Oral Surg 1999;87:27.

21. Bader JD, Martin JA, Shugars DA. Preliminary estimates of the incidence with the consequences of tooth fractures. J Am Dent Assoc 1995;126:1650.
22. Andreasen JO, Andreasen FM. Luxation injuries. In: Andreason JO, ed. Textbook and Color Atlas of Traumatic Injuries to the Teeth. 4th ed. Ames, Iowa: Blackwell Munksgaard; 2007.

23. Camp JH, Fuks AB. Pediatric endodontics: Endodontic treatment for the primary and young permanent dentition. In: Cohen S, Hargreaves KM, eds. Pathways of the Pulp. 10th ed. St. Louis, Mo: Mosby Elsevier; 2011:808-57.

24. Cvek M. Endodontic management and the use of calcium hydroxide in traumatized permanent teeth. In: Andreasen JO, Andreasen FM, Andersson L, eds. Textbook and Color Atlas of Traumatic Injuries to the Teeth. 4th ed. Ames, Iowa: Blackwell Munksgaard; 2007:598-657.

25. American Academy of Pediatric Dentistry. Guideline on pulp therapy for primary and immature permanent teeth. Reference Manual V 37/No 6 15/16 p. 244-52.

26. Felippe W, Felippe M, Rocha M. The effect of mineral trioxide aggregate on the apexification and periapical healing on teeth with incomplete root formation. Int Endod J 2006;39(1):2-9.

27. Trope M. Treatment of immature teeth with non-vital pulps and apical periodontitis. Endodontic Topics 2006;14:51-9.

28. Ding R, Cheung G, Chen G, et al. Pulp revascularization of immature teeth with apical periodontitis: a clinical study. J Endod 2009;35(5):745-9.

29. Cotti E, Mereu M, Lusso D. Regenerative treatment of an immature, traumatized tooth with apical periodontitis: report of a case. J Endod 2008;34(5):611-6.

30. Angle E. Classification of malocclusion. Dental Cosmos 1899;4:248-64.

31. Andrews LF. The six keys to normal occlusion. Am J Orthod 1972;62(3):296-309.

32. Thunold K. Early loss of the first molars 25 years after. Rep Congr Eur Orthod Soc 1970;349-65.

33. Plint DA. The effect on the occlusion of the loss of one or more first permanent molars. Rep Congr Eur Orthod Soc 1970;329-36.

34. Ong D, Bleakley E. Compromised first permanent molars: an orthodontic perspective. Australian Dental Journal 2010;55:2-14.

35. Williams JK, Gowans AJ. Hypomineralised first permanent molars and the orthodontist. Eur J Paediatr Dent 2003;4:129-32. 


\title{
Корневое развитие постоянных резцов и костей мандибулы в корреляции с планом лечения
}

\author{
Йордан Тарпоманов ${ }^{1}$, Севда Рималовска ${ }^{1}$, Ани Белчева ${ }^{1}$, Мирослава Йорданова ${ }^{2}$, Светла \\ Йорданова ${ }^{2}$, Мария Куклева ${ }^{1}$ \\ ${ }^{1}$ Кафедра детской дентальной медицины, Факультет дентальной медицины, Медицинский университет - Пловдив, Плов- \\ див, Болгария \\ ${ }^{2}$ Кафедра ортодонтии, Факультет дентальной медицины, Медицинский университет - Пловдив, Пловдив, Болгария
}

Адрес для корреспонденции: Йордан Тарпоманов, Кафедра детской дентальной медицины, Факультет дентальной медицины, Медицинский университет - Пловдив, бул. „Христо Ботев" № 2, 4000, Пловдив, Болгария E-mail: iortarp@yahoo.com Tel: 00359898455561

Дата получения: 02 июля 2017 Дата приемки: 11 сентября 2017

Дата онлайн публикации: 02 октября 2017

Дата публикации: 30 июня 2018

Ключевые слова: коренное развитие; метод Демирджяна; план лечения

\section{Образец цитирования:}

Tarpomanov Y, Rimalovska S, Belcheva A, Yordanova M, Yordanova S, Kukleva M. Root development of permanent incisors and mandibular molars in correlation with treatment plan. Folia Med (Plovdiv) 2018;60(2): 283-90.

doi: 10.1515/folmed-2017-0093
Введение: Резцы и коренные зубы играют основную роль в формировании и функционировании постоянного зубного ряда. Существует множество исследований на тему прорастания зубов и их корневого развития.

Цель: Провести исследование развития корней постоянных резцов и моляров нижней челюсти в соответствии с планом лечения и надлежащими протоколами лечения.

Материалы и методы: Метод Демирджяна использовался для оценки развития корней резцов и моляров нижней челюсти у детей в возрасте от 7 до 12 лет.

Результаты: У 7-летних детей значительный процент (76\%) нижних первых моляров нижней челюсти имел полную длину корня, но с открытыми верхушками. Значительная часть (82\%) из корней первых моляров нижней челюсти в возрасте 8 лет и 54\% у 9-летних детей была с открытыми верхушками. У первых моляров нижней челюсти были неполные корни у 10-летних (6\%) и даже у 11 -летних (4\%) детей. Мы обнаружили, что стадия Е в 10 лет - у $32 \%$ и у 24\% из 11-летних детей. Даже у 12-летних детей мы определили стадию Е на 4\% из панорамных рентгенограмм. Мы обнаружили полное развитие корней у всех детей в возрасте 12 лет.

Заключение: Практикующие стоматологи должны выждать до 10, 11 и даже 12-летнего возраста, когда уже оформилась фуркация, для удаления первых моляров. Надлежащее клиническое обследование и диагностические рентгенограммы должны быть выполнены до начала лечения моляров и резцов в возрасте от 7 до 12 лет. 